\title{
Nestedness of stream insects in Subtropical region: importance of inter-annual temporal scale
}

\author{
Luiz U. Hepp ${ }^{1,2}$ (D), Silvia V. Milesi² (D), Diane Nava² (1) \& Rozane M. Restello² (D)
}

\author{
1. Universidade Federal de Mato Grosso do Sul, Campus Três Lagoas, Av. Ranulpho Marques Leal, 3484, Distrito Industrial, 79613-000 Três Lagoas, MS, Brazil. \\ (luizuhepp@gmail.com) \\ 2. Programa de Pós-graduação em Ecologia, Universidade Regional Integrada do Alto Uruguai e das Missōes, Av. Sete de Setembro, 1621, $99709-910$ Erechim, RS, Brazil.
}

ABSTRACT. Stream insects use in different ways the stream habitats which affect patterns of species occurrence on stream. The nestedness is one of these patterns being an ecological mechanism that generates beta diversity. In this study, we verify the effects of temporal environmental variations on nestedness patterns of Chironomidae assemblages on subtropical streams. We collected chironomid larvae during winter and summer during three years $(2010,2011$ and 2012) in Brazilian Subtropical low-order streams (Erechim, state of Rio Grande do Sul, Brazil). We measured environmental variables in each stream. To assess if assemblages will show nested patterns intra- and interannual we used a NODF metric. We observed nestedness only in one year, this pattern was due to variation of limnological factors, which are directly associated with climatic conditions (precipitation and water temperature) and agricultural management (e.g. dissolved oxygen and nutrients). Climatological events affect Chironomidae community through the time. The variations on precipitation values could be one of the mainly factors that influence nestedness for this community. Finally, studies on nesting on time scales should consider inter-annual comparisons, as climatic variations are more evident.

KEYWORDS. Atlantic forest streams; beta-diversity; Chironomidae; climate changes; conservation.

Spatio-temporal variations exert influence on aquatic assemblages and to understand how the distribution of stream insects is structured, identify and measure these variations become extremely important (LEGENDRE et al., 2005; SÚAREZ, 2008). These variations induced by environmental process limit the species dispersal and are directly related to biotic and abiotic environmental factors (BUENo et al., 2003; CorTEzzi et al., 2009). Alterations on abiotic factors can be due to natural or anthropogenic actions and act on basic characteristics of stream habitat structure (MACE et al., 2010). Variations in precipitation can generate variations in the assemblages of aquatic ecosystems (BIsPo et al., 2006). These variations result in a decrease in the abundance of organisms and, consequently, in the species richness due to the drift caused by the flow increase in rivers and streams (Restello et al., 2014; Peralta \& Martin, 2015).

The precipitation intensity isone of the mainly factors that control the temporal distribution of stream insect assemblages (FLECKER \& FEIFAREK, 1994; RESTELlo et al., 2014; NAVA et al., 2015). The increase on the pluviosity levels intensifies the water flow, resulting on aquatic insects drift by physical perturbations. On the other side, on low water flow (i.e. dry periods) the abundance and richness of aquatic insects increase due to the higher habitat stability by water flow reduction (BAPTISTA et al., 2001; BisPo et al., 2006).
These climatic patterns change with the influence of El Niño and La Niña phenomena on hydrological cycles on aquatic environmental (MANJARRÉs-HERNÁNDEZ et al., 2021). The excess of rain caused by El Niño in the southern hemisphere can affect the abundance of stream insects, on the other hand, the drought provoked by El Niña decrease drastically the water flow causing an increase of some stream invertebrates (GARCIA et al., 2003; GARCIA \& SuÁrEZ, 2007; CAROnE et al., 2009). Drought periods compared to rainy seasons, generate greater stability for habitats and, consequently, for aquatic communities (PERALTA \& MARTIN, 2015). This is because the effects caused by high precipitation drastically alter the streambed heterogeneity, which has a direct effect on benthic assemblages.

Stream insects use in different ways the stream habitats which affect patterns of species occurrence on stream substrate (JURASINSKI et al., 2009). The nestedness is one of these patterns, being important for beta diversity in biological communities (AlmeidA-Neto et al., 2008; HeINo et al., 2009; Ulrich et al., 2012; MCCREADIE \& AdLER, 2018). Nestedness patterns occur when an assemblage with less richness is part of another assemblage with a greater species richness (BASELGA, 2010). The main factor that can cause a nested pattern on benthic assemblages can be the habitat characteristic (MILESI \& Melo, 2014; CERINI et al., 2020) or 
anthropogenic disturbance (HeINO et al., 2009; HuIÑOCANA et al., 2020). Therefore, the temporal scales besides the constant alterations on climatic changes can also affect these organisms (ANJos et al., 2011; RuHí et al., 2013; NAVA et al., 2015).These alterations could influence the variation in nestedness caused by variations in temporal scales (PETSCH et al., 2014). HeINo et al. (2009) studying aquatic insects for three years found a weak nested pattern but temporal stability in the assemblage nestedness. In addition, they found that nested pattern could be affected by hydrological disturbance, with communities of periods with high precipitation nested on communities of periods with low precipitation. In this way, the temporal variations mediated by water volume of the streams are important for the structure and composition of Chironomidae assemblages (Peralta \& Martin, 2015; NAVA et al., 2015).

Chironomidae (Diptera) is a very diverse and common insect family that are frequent in all the different aquatic ecosystems (FERRINGTON, 2008). The Chironomidae has different levels of tolerance to organic pollutants (SENSOLO et al., 2012; RESTELLO et al., 2014), and environmental plasticity, which indicates their use as model organisms in studies about ecological patterns and process on streams (Rosin \& TAKEDA, 2007). In addition, studies on the diversity and composition of Chironomidae do not present details on the structure patterns of these assemblages especially on beta diversity patterns. Thus, efforts to understand the structure and composition of Chironomidae assemblages on a time scale are important given the importance of the group for aquatic environments (Nava et al., 2015). We verify the effects of temporal environmental variations on Chironomidae assemblages distribution in subtropical streams. We expected a temporal nested pattern across the years, mainly caused by the precipitation variation, which will cause environmental changes in streams and, consequently, reduce the abundance and richness of Chironomidae. In the case of intra-annual variations of Chironomidae assemblages, we expect that between seasons we will not found nested pattern due to the well-distributed precipitation and temperature, as we are on subtropical region. This is one of the first studies with temporal nestedness using years and not season as time. We wanted to show the importance of a long time analyses for the comprehension of aquatic insect ecological patterns. Here, we consider the rainy period as an environmental disturbance that can generate the nested pattern for create greater instability on streambed habitats reducing the Chironomidae richness.

\section{MATERIAL AND METHODS}

Study area. The study was conducted in the Rio Uruguai river basin in southern Brazil $\left(27^{\circ} 12^{\prime}\right.$ '59" and $28^{\circ} 00^{\prime} 47^{\prime \prime} \mathrm{S}$; 52 $48^{\prime} 12^{\prime \prime}$ and $51^{\circ} 49^{\prime} 34^{\prime \prime} \mathrm{W}$; Fig. 1). The region is characterized by subtropical climate (Koppen $\mathrm{Cfb}$ type) with an average annual precipitation of $1,912 \mathrm{~mm}$ and average annual temperature of $17.6^{\circ} \mathrm{C}$ (Alvares et al., 2013). The vegetation consists of a mixture of Subtropical Forest, mostly composed of species with tropical-subtropical distribution and Araucaria forest with predominance of Araucaria angustifolia (OliveIRA-FILHO et al., 2015). The region has its area occupied by human activities, in particular by intensive agricultural practice ( $~ 80 \%$ of the total area; Rovani et al., 2019). We selected 10 small-order streams $\left(<3^{\text {rd }}\right.$ order $)$ with an approximate width of $2 \mathrm{~m}$, depth of about $0.3 \mathrm{~m}$ and substrate composed mainly of stones and leaves (RESTELLo et al., 2014).

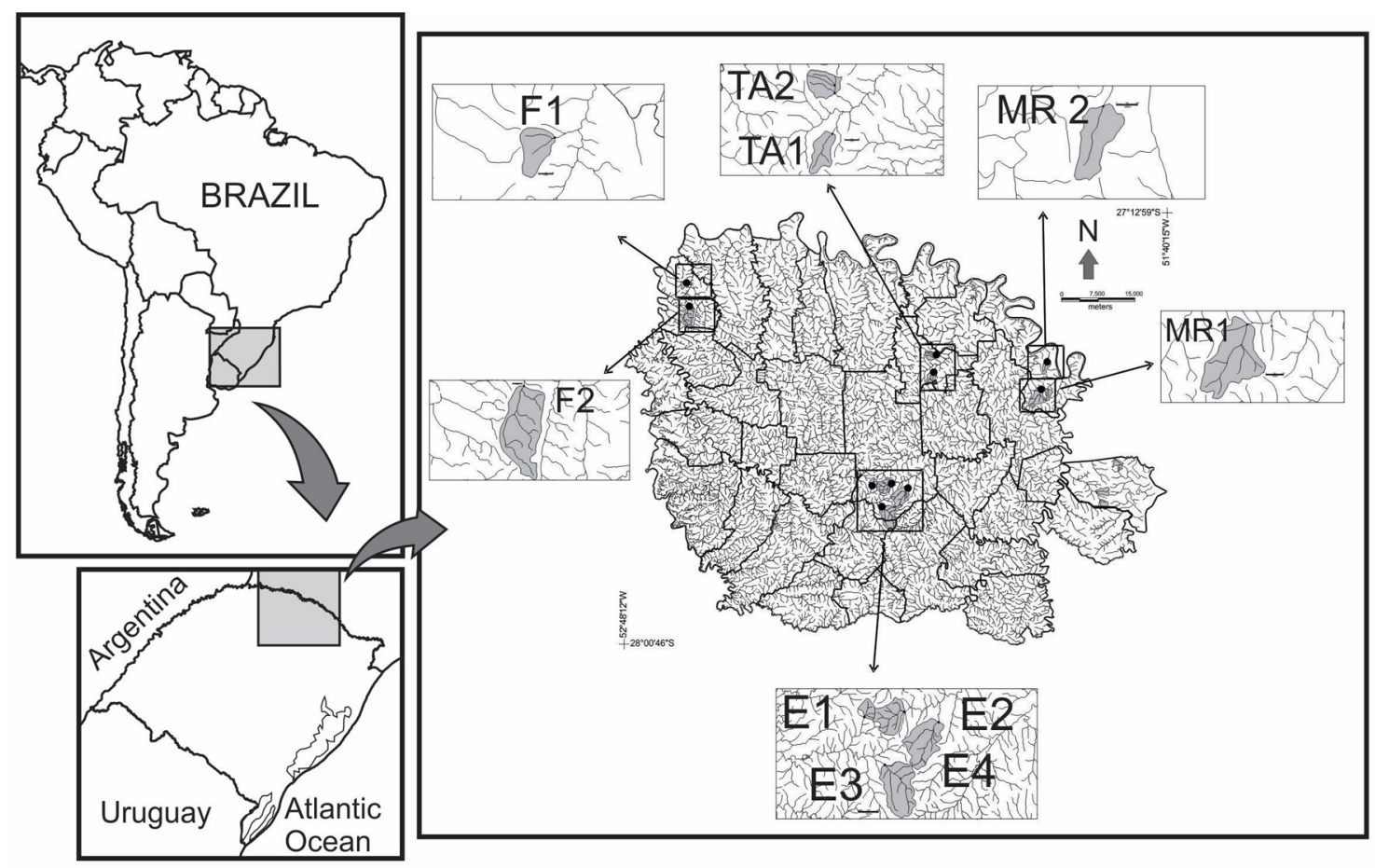

Fig. 1. Location of sampling sites in southern Brazil (F, Faxinalzinho city; E, Erechim; MR, Marcelino Ramos; TA, Três Arroios). 
Environmental variables. Water temperature, turbidity, electrical conductivity, total dissolved solids (TDS), dissolved oxygen (DO) and $\mathrm{pH}$ were measure in situ with a multi-parameter analyser HORIBA ${ }^{\circledR}$ U50. In addition, water samples were collected from streams and in the laboratory chemical analysis of dissolved organic carbon (DOC) and total dissolved nitrogen (TDN). These variables were measured on a Shimadzu ${ }^{\circledR}$ TOC-VCSH device.

The monthly precipitation data (monthly average) for the region was obtained through information from the National Institute of Space Research (CPTEC/INPE). According to Climate Prediction Center (NOAA; origin. cpc.ncep.noaa.gov) the La Niña phenomenon occurred in 2010 and 2011, while 2012 was a neutral year. The average monthly precipitation and temperature in 2010 was $276 \mathrm{~mm}$ and $17.5^{\circ} \mathrm{C}$, in 2011 was it $146 \mathrm{~mm}$ and $17^{\circ} \mathrm{C}$ and 2012 was it $121 \mathrm{~mm}$ and $18.8^{\circ} \mathrm{C}$, respectively.

Chironomidae larvae sampling. The organisms were collected during winter and summer from 2010 to 2012. In each stream, we collected three sub-samples on rocky substrate with a sampler Surber (mesh $250 \mu \mathrm{m}$; area $0.09 \mathrm{~m}^{2}$ ). The material was fixed in field with ethanol $80 \%$, packed in plastic bottles for further identification. After identification, Chironomidae larvae were dipped in potassium hydroxide solution $10 \%$ for 24 hours to bleaching. After, we made semi-permanent slides with Hoyer solution for identification to genus taxonomic level using TrivinHoStrixino \& Strixino (1995), EPLER (2001) and TrivinhoSTRIXINO (2011) identification keys.

Data analysis. To check the differences between the abiotic variables over the seasons (intra-annual variation) and between years (inter-annual variation) we used an analysis of variance (two way ANOVA). To assess the variation in abundance (log-transformed) richness and rarefied richness over the seasons (intra-annual variation) and between years (interannual variation) an analysis of variance (two way ANOVA) were used.

To assess if assemblages will show nested patterns on intra- and interannual we used to NODF metric (Nestedness metric based on Overlapping and Decreasing Fill; ALMEIDANETO et al., 2008). This analysis produces values range from 0 to 100 indicating nested subsets. The analysis was performed using SIM1 that produces a simulated model matrix in which all the arrangements are equally distributed. In addition, hundred random matrices are simulated for each null model, to obtain the expected average for NODF that was compared with the average of observed values. The NODF calculation requires an array of presence-absence, ordered by species richness, automatically generating nesting (GUIMARÃES \& Guimarães, 2006). Finally, there will be nested pattern when NODF of expected values are on average larger than NODF of observed values. All analyses were performed using statistical software R (R CORE TEAm, 2013) using functions of "vegan" package (OKSANEN et al., 2012).

\section{RESULTS}

Environmental variables. In inter-annual context the precipitation $\left(\mathrm{F}_{(2,57)}=11.1 ; \mathrm{p}<0.001\right)$, dissolved oxygen $(\mathrm{DO})\left(\mathrm{F}_{(2,57)}=24.4 ; \mathrm{p}<0.001\right), \mathrm{DTN}\left(\mathrm{F}_{(2,57)}=60.8 ; \mathrm{p}<0.001\right)$ and DOC $\left(\mathrm{F}_{(2,57)}=19.3 ; \mathrm{p}<0.001\right)$ varied between years (Supplementary Material 1). The year of 2010 showed lowest values of DOC $\left(21.3 \pm 3.5 \mathrm{mg} \mathrm{L}^{-1}\right)$, and highest values for DTN $\left(11.0 \pm 0.7 \mathrm{mg} \mathrm{L}^{-1}\right)$ and precipitation $(276.1 \pm 24.7 \mathrm{~mm})$ (Fig. 2). The year of 2012 showed the highest values for DO (13.6 $\pm 0.5 \mathrm{mg} \mathrm{L}^{-1}$ ) (Fig. 2). We detach that the year of 2011 showed lowest values of precipitation $(146.2 \pm 14.8 \mathrm{~mm})$ and highest values of DOC $\left(257.9 \pm 15.9 \mathrm{mg} \mathrm{L}^{-1}\right)$ (Fig. 2). The variables water temperature, $\mathrm{pH}$, electrical conductivity, turbidity, TDS and water current were similar between years.
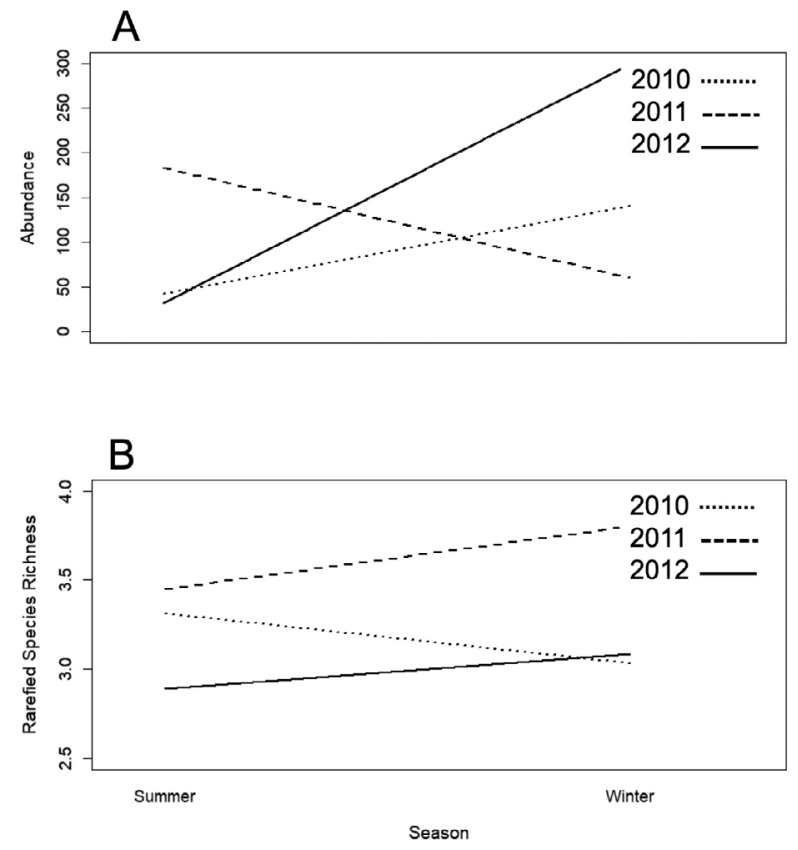

Fig. 2. Abundance and richness of Chironomidae (Diptera) in streams of southern Brazil in the summer and winter of 2010, 2011 and 2012.

In the intra-annual context for the year of 2010 the water temperature $(\mathrm{t}=8.8, \mathrm{df}=18, \mathrm{p}<0.001), \mathrm{DO}(\mathrm{t}=4.5$, $\mathrm{df}=18, \mathrm{p}<0.001)$, DTN $(\mathrm{t}=6.7, \mathrm{df}=18, \mathrm{p}<0.001)$ and precipitation $(\mathrm{t}=2.9, \mathrm{df}=18, \mathrm{p}=0.01)$ showed difference between seasons (Fig. 3). For all of these variables the higher values were registered on summer. For 2011 we found seasonally variation for water temperature $(\mathrm{t}=6.5, \mathrm{df}$ $=18, \mathrm{p}<0.001)$, DTN $(\mathrm{t}=-3.3, \mathrm{df}=18, \mathrm{p}=0.004)$, DOC $(\mathrm{t}=$ $-10.8, \mathrm{df}=18, \mathrm{p}<0.001)$ and precipitation $(\mathrm{t}=-6.6, \mathrm{df}=18$, 
$\mathrm{p}<0.001$ ) (Fig. 3). Expect for the water temperature the others variables values were high on winter. For 2012 the variables that showed differences between winter and summer was: water temperature $(\mathrm{t}=7.7, \mathrm{df}=18, \mathrm{p}<0.001), \mathrm{DO}(\mathrm{t}=-3.1$, $\mathrm{df}=18, \mathrm{p}=0.008)$, DOC $(\mathrm{t}=-4.8, \mathrm{df}=18, \mathrm{p}<0.001)$ and precipitation $(\mathrm{t}=-1,236.0, \mathrm{df}=18, \mathrm{p}<0.001)$ (Fig. 3). Expect for the water temperature the others parameters values were higher on winter.
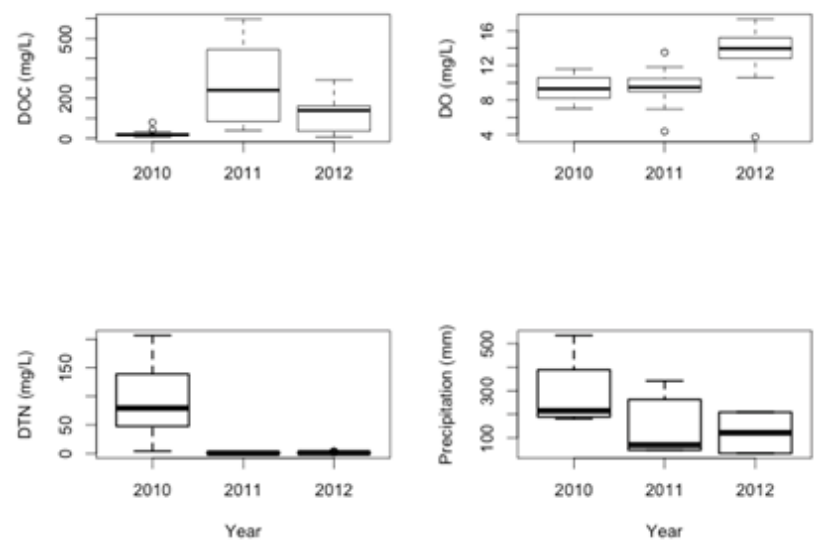

Fig. 3. Boxplot of dissolved organic carbon (DOC), dissolved oxygen (DO), dissolved total nitrogen (DTN) and precipitation in streams of southern Brazil in the summer and winter of 2010, 2011 and 2012.
Chironomidae assemblages and nested pattern. A total of 7,568 chironomids larvae were collected, distributed in 49 genera during three years (Supplementar Material 2). The most abundant genera were Pentaneura (7.4\%), Polypedilum (7.4\%), followed by Rheotanytarsus (7.2\%) and Cricotopus/Orthocladius (7.0\%). Of the total genera 36 showed abundance less than $1 \%$. Chironomidae abundance showed anintra-annual variation $\left(\mathrm{F}_{(1,54)}=5.5 ; \mathrm{p}=0.02\right)$ (Fig. 4). We also observed an interaction between seasons, but depending on the year. Winter showed more abundance of chironomids larvae on 2010 and 2012. However, we found the inverse pattern for 2011 where summer present more organisms than winter. For rarefied richness, the variation was inter-annual $\left(\mathrm{F}_{(1,54)}=7.1 ; \mathrm{p}=0.001\right)$ (Fig. 4). The highest richness was observed on 2011 for both seasons.

We found a nested pattern for Chironomidae assemblages between years (inter-annual) $\left(\mathrm{F}_{(1,56)}=\right.$ 23.4; $<<0.001$; Fig. 5). However, between the seasons (intraannual), we observed nested pattern only for 2010 and $2012\left(\mathrm{~F}_{(1,17)}=91.0 ; \mathrm{p}<0.001 ; \mathrm{F}_{(1,17)}=18.6 ; \mathrm{p}<0.001\right.$, respectively), whereas 2011 did not show nested pattern $\left(\mathrm{F}_{(1,17)}=51.1, \mathrm{p}<0.001 ;\right.$ Fig. 5).
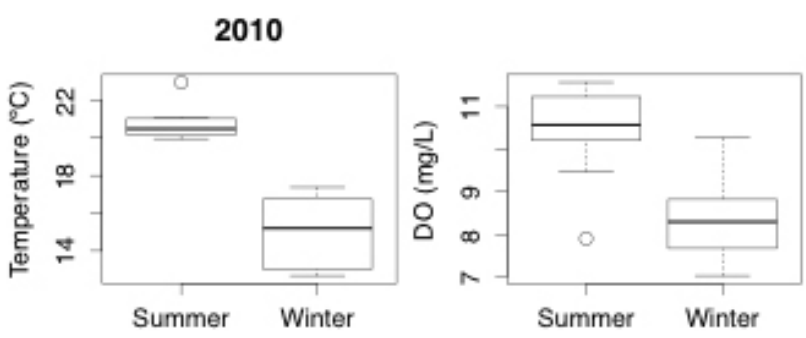

2011
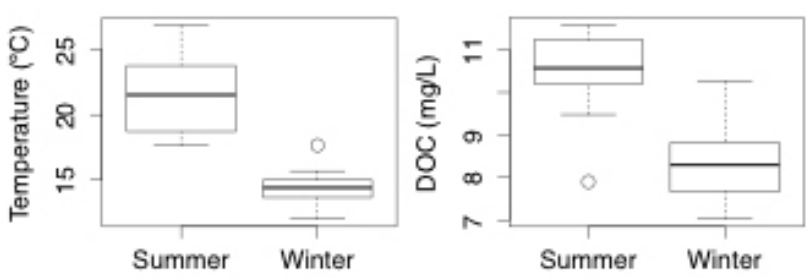

2012
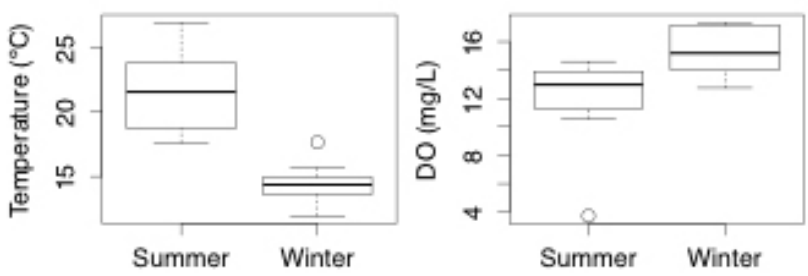
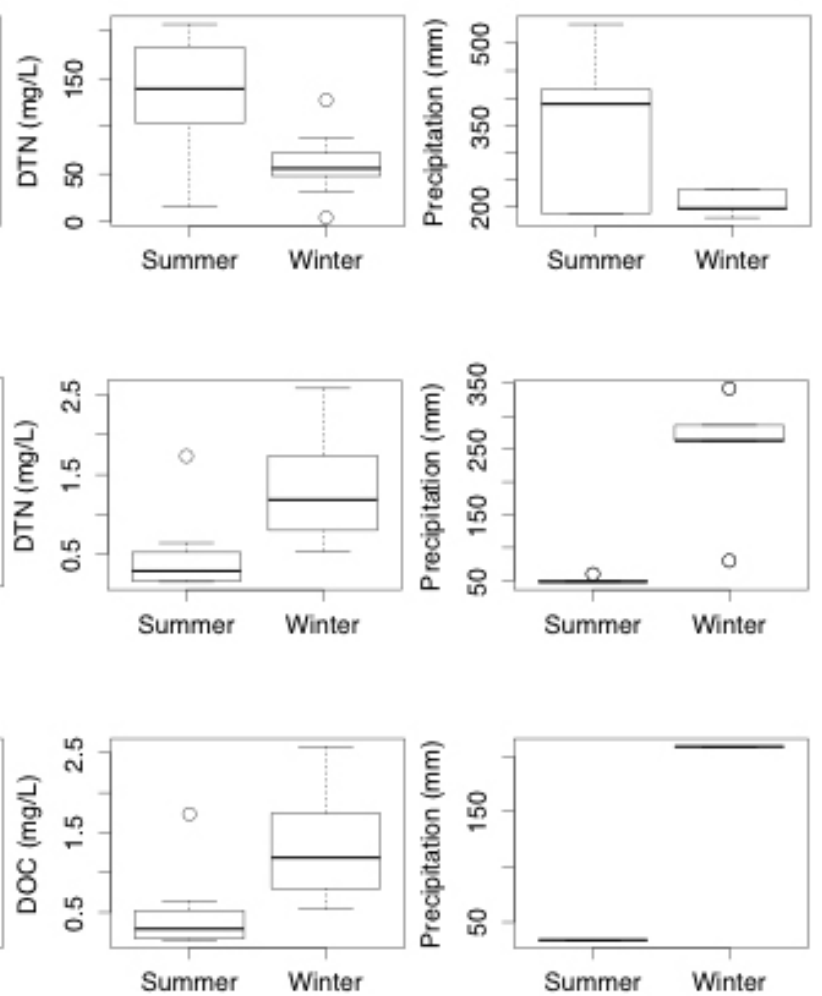

Fig. 4. Boxplot of water temperature, dissolved organic carbon (DOC), dissolved oxygen (DO), dissolved total nitrogen (DTN) and precipitation in the summer and winter of 2010, 2011 and 2012 in streams of southern Brazil (only variables with significant differences for each year). 

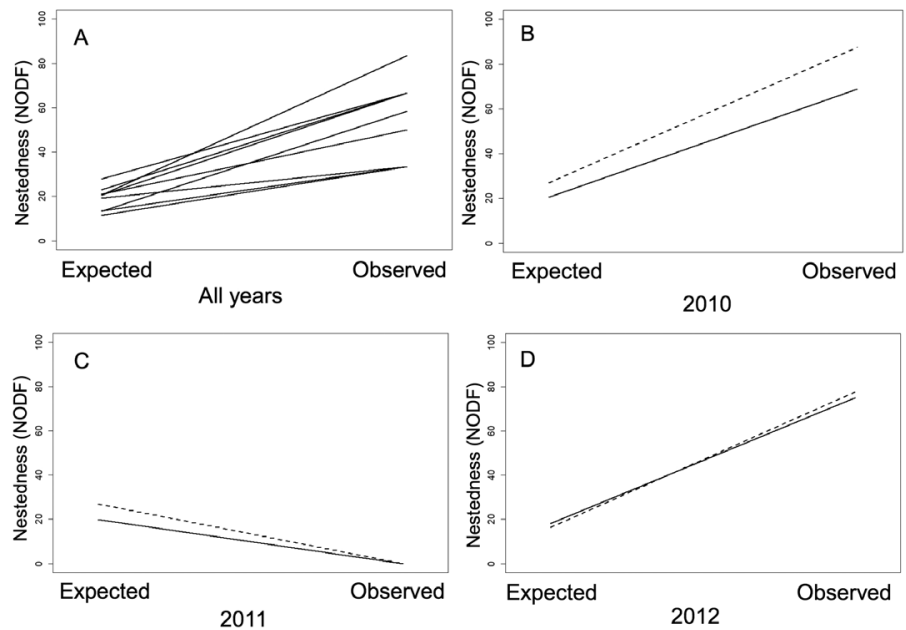

Fig. 5. NODF nestedness of Chironomidae (Diptera) assemblages in streams of southern Brazil in the summer and winter of 2010, 2011 and 2012. (A) Each line represents a stream independent of intra- and inter-annual factor. (B, C, D) Dotted lines represent winter data and continuous lines represent summer data. In these graphs, the individual information for each stream was grouped to assess intra-annual nestedness.

\section{DISCUSSION}

In this study, we observed the influence of the temporal scale in the Chironomidae assemblages, demonstrating that time is a crucial factor in the structuring of aquatic communities. According to RESTELLO et al. (2014) the greatest variation in chironomid assemblages occur between seasons and not between the years. The authors found that $50 \%$ of the observed variation is explained by physical and chemical changes that occur between the seasons. In contrast, NAVA et al. (2015) state that the variation in the abundance and richness of Chironomidae occurs over the years and between seasons mainly modulated by precipitation. In our study, the abundance variation between seasons can be attributed to differences in precipitation levels, water temperature, dissolved oxygen, DOC and DTN values. The precipitation increase the disturbance in the stream physical environment causing changes on streambed structure increasing local heterogeneity (BISPO et al., 2006). Which can cause chemical changes that favor the colonization of new species thereby altering the composition of stream insect assemblages (GARCIA \& SUÁREZ, 2007). Agricultural impact increases the carbon emissions and nitrogen dissolved that directly affect the ecological patterns of Chironomidae and others aquatic insect assemblages, such as Ephemeroptera, Plecoptera and Trichoptera (NAVA et al., 2015; HuiÑoCANA et al., 2020).

The intra-annual nestedness was verified only in one year. This pattern was due to variation of limnological factors which are directly associated with climatic conditions (precipitation and water temperature) and agricultural management (DO, DOC and DTN) of the study area. Precipitation, water temperature, DOC and DTN were the variables that showed significant changes in the years with nestedness and therefore may have influenced on the chironomid assemblages. The origin of carbon and nitrogen compounds can be autochthonous and/or allochthonous in aquatic systems. According, in drainage areas with a predominance of agricultural activities and consequently with scarce riparian vegetation facilitate the contribution of these compounds to the streams by runoff (SENSOLO et al., 2012). Generally high concentrations of organic matter in streams can cause changes in physical and chemical conditions that alter the structure and composition of aquatic communities. The nitrogen in the water column stimulates the eutrophication process, allowing the algae growth, and reducing the diversity, facilitating the colonization of species that are tolerant to these conditions (RESTELLO, 2012). In addition, high levels of DTN in streams, reflects the land use and occupancy of their respective catchment areas and the rivers as natural collectors of the landscape (NIYOGI et al., 2007). These changes can act as an environmental filter on Chironomidae assemblages, forming assemblies with less species richness which were subsets of the richest ones, featuring nested pattern. With our results we can conclude that intra-annual temporal nestedness is related to impacts from climatic changes (i.e. precipitation) and powered by agricultural activities.

Our study showed that environmental changes generate nested patterns between years in Chironomidae assemblages corroborating our hypothesis. The variables that vary over the years were precipitation, DOC, DTN and dissolved oxygen. When environmental variation changes occur in these systems directly influence the structure of aquatic communities contributing for nested patterns. In addition, these changes on environmental variables were more evident in stream with predominance of agricultural activities, where the surface facilitated carries of chemicals compounds from adjacent areas to the water column. Subtropical regions present four well-defined seasons, with this, during a year we can registered notice variations on abiotic parameters, adding the influence of such climatological phenomenon, we pointed out the importance of annual replications on researches with streams fauna. The information generated 
by nestedness analysis can be used as basis for long-standing environmental monitoring programs on subtropics. It is necessary that these programs, when define the sampling design should consider the variations that occur intra- and interannually.

We consider that environmental variables that differ between years could be related to climatological phenomenon that was registered in three years of study. This is evident when we consider the precipitation variations that are frequent in the subtropical region, which are further enhanced by climatic phenomena. Making modifications on Chironomidae distribution intra and interannually that can be noted thought the nested pattern of the community. We detach that in the year were precipitation were the lowest, the richness were high, this precipitation pattern probably homogenize the habitat increasing species co-existence (RESTELLO et al., 2014). PINHA et al. (2016) registered nestedness on Chironomidae assemblage during the flood period justifying the result saying that inundations can homogenize limnological conditions.

The nested pattern occurs due to environmental variations that were related to nutrients (e.g. carbon and nitrogen), i.e., variables indirectly influenced by land uses (HeINo et al., 2009). For example, in 2011, the precipitation values were lower compared to 2010 (146 $\mathrm{mm}$ and 276 $\mathrm{mm}$, respectively) and an increase on DOC values was registered, probably due to a increasing in leaching process and consequently carbon liberation from leaves. Meanwhile, in 2010 values of precipitation were higher, increasing the DTN, it could be an indirect effect of anthropogenic activities, such as remove of riparian vegetation and the increase of nitrogenized residuals to the streams, changing the community distribution. The result shows how Chironomidae can be used on the monitoring of water quality being sensitive to modification on water chemical and physical characteristics. The variation on precipitation, DOC, DTN and dissolved oxygen influenced the community nested pattern. The effect of environmental variables on the nestedness of aquatic communities is a common pattern on nature (HEINO et al., 2009). But, this effect can be intensified by disturbances from natural origin (e.g. climatic changes) and also byanthropic actions that affect directly the limnological characteristics, like DTN and DOC, which can indirectly exerted influence on climate (FLORENCIO et al., 2011).

In the year that rains less, communities were not nested, meanwhile in years that rain more community showed a nested pattern. Usually, nestedness is naturally observed in nature (HEINO et al., 2009), being generated by modifications on environmental characteristics. For PETSCH et al. (2014) studying Chironomidae assemblages the nested pattern showed between months was influenced by flood disturbance. In this case, the increase on precipitation can cause the disturbance on Chironomidae assemblages (e.g. high flow velocity, organisms dislodgment, decrease on food resources and refuges), generating the nested pattern (FLORENCIO et al., 2011). In addition, we observed that agricultural activities influence the distribution of Chironomidae assemblages and their intensification can generate species loss, which can be detected because of the nested pattern.

The variations on precipitation values could be one of the mainly factors that influence the Chironomidae assemblages distribution which generate a nested pattern. The temporal nestedness study should be realized between years, because they are sensible to climatic variations that could happen randomly. In other words, to analyze temporal nestedness it is necessary inter-annual samples, because intra-annual vary too much in accordance with climatological events. Moreover, for regions with different precipitation values, like tropical stream (e.g. rainy and dry period) the intra-annual pattern in values could be different from subtropical regions where the precipitation were well distributed through the year. Thus, we can infer that temporal nestedness studies on subtropical streams must be investigated by annual and not seasonal replication.

Supplementary Material 1. Environmental variables measured in streams in the summer and winter periods during the years 2010, 2011 and 2012

Supplementary Material 2. Abundance of Chironomidae collected in streams in the summer and winter periods during the years 2010, 2011 and 2012 .

Acknowledgements. We thank the support of Gabriela Gabriel, Pedro Moraes and Wanessa Deliberalli to support in the field and laboratoty works. DN thanks to Coordenação de Aperfeiçoamento de Pessoal de Nivel Superior (CAPES) for scholarship. LUH received financial support of the Conselho Nacional de Desenvolvimento Cientifico e Tecnológico (CNPq, Proc. \#421632/2016-0) and grants (\#305203/2017-7).

\section{REFERENCES}

Almeida-Neto, M. P.; Guimarães, P.; Guimarães-Jr., P. R.; Loyola, R. D. \& ULRICH, W. 2008. A consistent metric for nestedness analysis in ecological systems: reconciling concept and measurement. Oikos 117:1227-1239.

Alvares, C. A.; Stape, J. L.; Sentelhas, P. C.; Moraes, G.; Leonardo, J. \& SparoveK, G. 2013. Köppen's climate classification map for Brazil. Meteorologische Zeitschrift 22:711-728.

Anjos, A. F.; Takeda, A. M. \& Pinha, G. D. 2011. Distribuição espacial e temporal das larvas de Chironomidae em diferentes ambientes do complexo - rio Baía, Estado do Mato Grosso do Sul, Brasil. Acta Scientiatum, Biological Sciences 33:417-426.

Baptista, D. F.; Buss, D. F.; Dorvillé, L. F. M. \& Nessimian, J. L. 2001. Diversity and habitat preference of aquatic insects along the longitudinal gradient of the Macaé river basin, Rio de Janeiro, Brazil.Revista Brasileira de Biologia 61:249-258.

Baselga, A. 2010. Partitioning the turnover and nestedness components of beta-diversity. Global Ecology and Biogeography 19:134-143.

Bispo, P. C.; Oliveira, L. G.; Bini, L. M. \& Sousa, K. G. 2006. Ephemeroptera, Plecoptera and Trichoptera from riffles in mountain streams of Central Brazil: environmental factors influencing the distribution e abundance of immatures. Brazilian Journal of Biology 66:611-622.

Bueno, A. A. P.; Bond-Buckup, G. \& Ferreira, B. D. P. 2003. Estrutura da comunidade de invertebrados bentônicos em dois cursos d'água do Rio Grande do Sul, Brasil. Revista Brasileira de Zoologia 20:115-125.

Carone, M. T.; Simoniello, T.; Manfreda, S. \& Caricato, G. 2009. Watershed influence on fluvial ecosystems: an integrated methodology for river water quality management. Environmental Monitoring and Assessment 152:327-342. 
Cerini, F.; Bologna, M. A. \& Vignoli, L. 2020. Nestedness-patterns of Odonata assemblages in artificial and natural aquatic habitats reveal the potential role of drinking troughs for aquatic insect conservation. Journal of Insect Conservation 24:421-429.

Cortezzi, S. S.; BisPo, P. C.; PACiÊnCIA, G. P. \& LeIte, R. C. 2009. Influência da ação antrópica sobre a fauna de macroinvertebrados aquáticos em riachos de uma região do cerrado do sudoeste do Estado de São Paulo. Iheringia, Série Zoologia 99:36-43.

EPLER, J. 2001. Identification manual for the larval Chironomidae (Diptera) of North and South Carolina. Orlando, Departament of Enviromental and Natural Resources. 526p.

Ferrington, L. C. 2008. Global diversity of non-biting midges (Chironomidae; Insecta-Diptera) in freshwater. Hydrobiologia 595:447-455.

FleCKer, A. S. \& FeIfaReK, B. 1994. Disturbance and temporal variability of invertebrate assemblages in two Andean streams. Freshwater Biology 31:131-142.

Florencio, M.; Díaz-Paniagua, C.; Serrano, L. \& Bilton, D. T. 2011. Spatio-temporal nested patterns in macroinvertebrate assemblages across a pond network with a wide hydroperiod range. Oecologia 166:469-483.

Garcia, A. M.; Vieira, J. P.; Winemiller, K. O. \& Grimm, A. M. 2003. Effects of 1997-1998 El Niño on the dynamics of the shallow-water fish assemblage of the Patos Lagoon estuary (Brasil). Estuarine, Coastal and Shelf Science 57:489-500.

GARCÍA, P. E. \& SuÁREZ, D. A. A. 2007.Community structure and phenology of chironomids (Insecta: Chironomidae) in a Patagonian Andean stream. Limnologica 37:109-117.

Guimarẽes, P. R. \& Guimarães, P. 2006. Improving the analyses of nestedness for large sets of matrices. Environmental Modelling \& Software 21:1512-1513.

Heino, J.; Mykrä, H. \& Muotka, T. 2009. Temporal variability of nestedness and idiosyncratic species in stream insect assemblages. Diversity and Distribution 15:198-206.

Huiñocana, J. C. S.; Albertoni, E. F.; Picolotto, R. C.; Milesi, S. V. \& HePP, L. U. 2020. Nestedness of insect assemblages in agricultureimpacted Atlantic forest streams. Annales de Limnologie - Internation Journal of Limnology 56(3):1-9.

Jurasinski, G.; Retzer, V. \& Beierkuhnlein, C. 2009. Inventory, differentiation, and proportional diversity: a consistent terminology for quantifying species diversity. Oecologia 159:15-26.

Legendre, P.; Bocard, D. \& Peres-Neto, P. R. 2005. Analyzing beta diversity: partitioning the spatial variation of community composition data. Ecological Monographs 75:435-450.

Mace, G. M.; Collen, B.; Fuller, R. A. \& Boakes, E. H. 2010. Population and geographic range dynamics: Implications for conservation planning. Philosophical Transactions 365:3743-3751.

Manjarrés-Hernández, A.; Guisande, C.; García-Roselló, E.; Heine, J.; Pelayo-Villamil, P.; Pérez-Costas, E.; González-Vilas, L.; González-Dacosta, J.; Duque, S. R.; Granado-Lorencio, C. \& Loвo, J. M. 2021. Predicting the effects of climate change on future freshwater fish diversity at global scale. Nature Conservation 43:1-24.

MCCREAdIE, J. W. \& AdLER, P. H. 2018. Patterns of regional beta diversity in a widespread group of North American aquatic insects. Freshwater Science 37:631-639.

MiLesI, S. V. \& Melo, A. S. 2014. Conditional effects of aquatic insects of small tributaries on mainstream assemblages: position within drainage network matters. Canadian Journal of Fisheries and Aquatic Sciences 71:1-9.

Nava, D.; Restello, R. M. \& HepP, L. U. 2015. Intra- and inter-annual variations in Chironomidae (Insecta: Diptera) communities in subtropical streams. Zoologia 32:207-214.
Niyogi, D. K.; Koren, M.; Arbuckle, C. J. \& Townsend, C. R. 2007. Stream communities along a catchment land-use grandient: subsidystress responses to pastoral development. Environmental Management 39:213-225.

Oksanen, J.; Blanchet, F. G.; Kindt, R.; Legendre, P.; O’Hara, R. G.; Simpson, G. L.; Solymos, P.; Stevens, M. H. H. \& Wagner, H. 2012. 'Vegan: Community Ecology Package'. R package version 1.17-0. Available at $<\mathrm{http}: / /$ CRAN.R-project.org/package=vegan $>$.

Oliveira-Filho, A. T.; BudKe, J. C.; JaRenKow, J. A.; EISENLOHR, P. V. \& Neves, D. R. M. 2015. Delving into the variations in tree species composition and richness across South American subtropical Atlantic and Pampean forests. Journal of Plant Ecology 8:242-260.

Peralta, R. H. L. \& Martin, G. M. T. 2015. Densidad larval de Chironomidae (Insecta: Diptera) em un meandro del río Bogotá (Cajicá, Colombia) durante La niña 2011. Revista Facultad de Ciencias 11(1):48-67.

Petsch, D. K.; Pinha, G. D.; Dias, J. D. \& Takeda, A. M. 2014. Temporal nestedness in Chironomidae and the importance of environmental and spatial factors in species rarity. Hydrobiologia 745:181-193.

Pinha, G. D.; Petsch, D. K. ; Ragonha, F. H.; Guglielmetti, R.; Bilia, C. G.; TRAmonte, R. P. \& TAKedA, A. M. 2016. Benthic invertebrates nestedness in flood and drought periods in a Neotropical floodplain: looking for the richest environments. Acta Limnologica Brasiliensia (Online) 28:1-10.

R Core Team. 2013. A Language and Environment for Statistical Computing. Vienna, R Foundation for Statistical Computing. Available at $<$ http://www.R-project.org $>$.

Restello, R. M.; Biasi, C.; Moraes, P. F. M. M.; Gabriel, G. \& Hepp, L. U. 2014. Composition and diversity of the Chironomidae in subtropical streams: effects of environmental predictors and temporal analysis. Acta Limnologica Brasiliensia 26:215-226.

Restello, R. M.; Hepp, L. U.; Menegatti, C.; Decian, V. \& HenkeOliveira, C. 2012. Efeito das características da área de drenagem sobre a distribuição de Chironomidae (Diptera) em riachos do Sul do Brasil. In: Santos, J. E.; Zanin, E. M. \& Moschini, L. E. orgs. Faces da Polissemia da Paisagem - Ecologia, Planejamento e Percepção. São Carlos, Rima, v. 4, p. 324-340.

Rosin, G. C. \& TAKEDA, A. M. 2007. Larvas de Chironomidae (Diptera) da planície de inundação do alto rio Paraná: distribuição e composição em diferentes ambientes e períodos hidrológicos. Acta Scientiarum, Biological Sciences 29:57-63.

Rovani, I. L.; Santos, J. E.; Decian, V. S. \& Zanin, E. M. 2019. Assessing Naturalness Changes Resulting from a Historical Land Use in Brazil South Region: An Analysis of the 1986-2016 Period. Journal of Environmental Protection 10:149-163.

Ruhí, A.; Boix, D.; Gascón, S.; Sala, J. \& Quintana, X. D. 2013. Nestedness and successional trajectories of macroinvertebrate assemblages in man-made wetlands. Oecologia 171:545-556

Sensolo, D.; Hepp, L. U.; Decian, V. \& Restello, R. M. 2012. Influence of lescape on assemblages of Chironomidae in Neotropical streams. Annales de Limnologie -International Journal of Limnology 48:391-400.

SúAREZ, Y. R. 2008. Variação espacial e temporal na diversidade e composição de espécies de peixes em riachos da bacia do Rio Ivinhema, Alto Rio Paraná. Biota Neotropica 8:197-204.

Trivinho-Strixino, S. 2011. Larvas de Chironomidae. Guia de identificação. São Carlos, Departamento de Hidrobiologia/Laboratório de Entomologia Aquática/UFSCar. 371p.

Trivinho-Strixino, S. \& Strixino, G. 1995. Larvas de Chironomidae (Diptera) do estado de São Paulo: guia de identificação e diagnose dos gêneros. São Carlos, PPG- RRN/UFSCar. 229p.

Ulrich, W.; Almeida-Neto, M. \& Gotelli, N. J. 2012. A consumer's guide to nestedness analysis. Oikos 118:3-17. 